\title{
Effect of Organic Acids with Probiotic Supplementation on Immunity and Blood Biochemical Status of Broiler Chicken
}

\author{
G.M. Jadhao ${ }^{1 *}$, D.H. Sawai ${ }^{1}$, H.N. Rewatkar ${ }^{1}$, R.P. Kolhe ${ }^{1}$, \\ A.P. Bansod ${ }^{1}$ and J.D. Nandeshwar ${ }^{2}$ \\ ${ }^{1}$ Department of Animal Nutrition, Post Graduate Institute of Veterinary and \\ Animal Sciences, Akola (MS), India \\ ${ }^{2}$ Nagpur Veterinary College, Nagpur, India \\ *Corresponding author
}

\section{A B S T R A C T}

\section{Keywords}

Organic acids, Probiotic, Sodium diformate,

Saccharomyces

cerevisiae, Immunity, Blood biochemical, broilers

Article Info

Accepted:

15 January 2019

Available Online:

10 February 2019
The present research was conducted to study the effect of organic acids with probiotic supplementation on immunity and blood biochemical status of broiler chicken. A total number of 300 birds were reared for a period of forty two days with dietary treatments; $\mathrm{T}_{0}$ - control diet as per BIS (2007), $\mathrm{T}_{1}$ - control + sodium diformate @ 0.2\%, $\mathrm{T}_{2}$ - control + sodium diformate @ 0.2 + probiotic @0.02\%, $\mathrm{T}_{3}$ - control + blends of organic acids $@ 0.2 \%, \mathrm{~T}_{4}-$ control + blends of organic acids @ $0.2 \%+$ probiotic @0.02\%. Each treatment consist of sixty birds with four replicates containing fifteen birds per replicate. Two birds from each replicate of average body weight were selected and blood samples at the end of 42 days were collected to determine immune titre and blood biochemical parameters. Immune titre of birds were found to be non-significant with increased antibody titre in all treatment groups than control. Blood biochemical parameters viz., total protein, albumin, globulin and BUN were found to be significant. However there was decreased level of cholesterol in all treatment groups than control.

\section{Introduction}

Poultry is one of the quickest growing industry in India and furthermore world. Present day modern poultry industry has accomplished marvelous gains in the proficient and efficient creation of high quality and safe chicken meat, eggs and poultry byproducts. Meanwhile as making gains underway and effectiveness, the industry needs to increase the prosperity and thriving of the birds and limit the effect of the business on the earth. The use of feed additives has been a basic bit of gaining this ground. Feed additives are essentially included to enhance the productivity of the bird's development as well as laying capacity, prevent diseases and enhance feed utilization. Antibiotic feed additives as growth promoters have for quite some time been added to poultry feed to stabilize the intestinal microbial flora, improve the general 
performances and prevent some specific intestinal pathogens (Hassan et al., 2010). The prohibition on use of antibiotics as growth promoters in European Union since 2006 grasped the finding of differentiating alternative to antibiotics in farm animal nutrition (Attia et al., 2006, 2012; El-Deek et al., 2011). Antibiotic-resistant bacteria (whose number is growing well ordered) are considered furthermore a social issue with a high reasonable impact due to the extending number of hospitalizations. The finding of natural molecule as an elective choice to antimicrobials could upgrade welfare both in birds and people. A couple of different choices to anti-microbial growth promoters have been proposed, for instance organic acids (Kral et al., 2011), probiotics (Capcarova et al., 2008), phytogenic feed additives (Gálik and Rolinec, 2011), products bees (Petruska et al., 2012) and enzymes (Bentea et al., 2010). Basically, organic acids incorporate carboxylic acids and unsaturated fats having a chemical formula of $\mathrm{R}-\mathrm{COOH}$, where $\mathrm{R}$ represents to chain length of the acids. Organic acids have growth-promoting properties (Fascina et al., 2012), likewise its utilization could stimulate the natural immune response (Lohakare et al., 2005; Abbas et al., 2013). Probiotics are either single as well as blend of live microbial culture which elevate health benefits to the host (Fuller, 1992). Strategy for probiotics activity incorporates competition with receptor sites in the intestinal tract, production of specific metabolites (short organic fatty acids, hydrogen peroxide, other metabolites possessing antimicrobial activity) and immune stimulation effect (Madsen et al., 2001; Sherman et al., 2009). Saccharomyces known to offer a good quality protein and Bcomplex vitamins. Due to immunomodulatory properties, yeast extract, the non-antimicrobial product is recommended to be the potential non-anti-microbial option for diminishing pathogenic micro-organisms in turkey production (Huff et al., 2010). Microencapsulation of probiotic can be utilized to upgrade the viability during processing and also for the targeted delivery in gastrointestinal tract. Considering the wide scope for the research of combination of single or blends of organic acids with probiotic to give optimum synergistic effect on immunity and blood biochemical performance of broiler chicken, the present study is planned.

\section{Materials and Methods}

An experiment was conducted to study the effect of organic acids with probiotic supplementation on immunity and blood biochemical status of broiler chicken. A total 300 broilers were reared for six weeks with dietary treatments, $\mathrm{T}_{0}$ (control diet as per BIS, 2007), $\mathrm{T}_{1}$ (control plus sodium-diformate @ $0.2 \%), \mathrm{T}_{2}$ (control plus sodium diformate @ $0.2 \%$ plus probiotic @ $0.02 \%$ ), $\mathrm{T}_{3}$ (control plus blends of organic acid @ 0.2\%), $\mathrm{T}_{4}$ (control plus blends organic acid @ 0.2\% plus probiotic@0.02\%) as shown in table 1. Each treatment consisted of sixty birds with four replicates containing fifteen birds in each replication. The Probiotic contained encapsulated Saccharomyces cerevisiae @ 1 $\mathrm{x} 10^{10} \mathrm{CFU} / \mathrm{g}$. Blends of organic acid consisted of buffered organic acids like Calcium Propionate, Sodium Formate, Fumaric acid, Sorbic acid and Citric acid in equal quantity. The birds were reared on deep litter system and standard managemental practices were followed during the entire experimental period. Individual body weight of each bird was recorded at weekly interval and bodyweight gain was calculated as mean of each replicate. The birds from the experimental trial were assessed for the antibody titer against the New Castle Disease (ND) at 42 days of age. Blood samples from eight birds of each treatment (two from each replicate with average body weight) were 
collected toward the finish of test. The blood samples were collected via wing vein from each bird and serum was isolated by centrifugation at 3000 RPM for 10 minutes and kept at $-20^{\circ} \mathrm{C}$ till further investigation. These serum samples were used for Haemagglutination Inhibition (HI) test as per procedure of O.I.E (1992) to detect the antibody titer against New Castle Disease. Two fold serial dilutions of antigen and serum was used as antigen for HI test. The HI titer was expressed as $\log _{2}$ value of the highest dilution of serum causing complete inhibition of 4HA unit of antigen and given in table 2 . Biochemical parameters included estimation of Total protein, Albumin, BUN, Serum cholesterol utilizing biochemical kits produced by AGD Biomedicals PVT.LTD with the assistance of AGD Biochemistry Auto-analyzer whereas serum Globulin was determined by subtracting Albumin from total protein and depicted in table 2 . The collected data during the study was analyzed statistically as per Snedecor and Cochran (1994) by utilizing Statistical Package for the Social Sciences (SPSS) Version 17.0.

\section{Results and Discussion}

Average mean values of $\mathrm{HI}$ titres indicated non-significant differences in different groups and values $\left(\log _{2}\right)$ recorded as $4 \pm 0.42$, $4.13 \pm 0.52,4.25 \pm 0.49,4.38 \pm 0.6$ and $5 \pm 0.68$ in $\mathrm{T}_{0}, \mathrm{~T}_{1}, \mathrm{~T}_{2}, \mathrm{~T}_{3}$ and $\mathrm{T}_{4}$ with pooled mean value $4.35 \pm 0.24$ treatment respectively The values of serum total protein $(\mathrm{mg} / \mathrm{dl})$ were $\mathrm{T}_{0}$ $2.95 \pm 0.25, \mathrm{~T}_{1}-3.14 \pm 0.16, \mathrm{~T}_{2}-3.24 \pm 0.26, \mathrm{~T}_{3}$ $3.69 \pm 0.14$ and $\mathrm{T}_{4}-4.06 \pm 0.1$ with mean 3.41 \pm 0.1 . Among all the Treatment group $\mathrm{T}_{4}$ fed with mixture of organic acids and probiotic differed significantly from $T_{0}, T_{1}$ and $\mathrm{T}_{2}$ with numerically highest value among all the treatments however lowest serum total protein value was observed in control group. The values of serum albumin $(\mathrm{mg} / \mathrm{dl})$ for treatment group $\mathrm{T}_{0}$ to $\mathrm{T}_{4}$ with mean were $1.36 \pm 0.1, \quad 1.43 \pm 0.1, \quad 1.54 \pm 0.12, \quad 1.82 \pm 0.12$,
$1.86 \pm 0.1$ and $1.6 \pm 0.06$ respectively. The data pertaining values of serum albumin subjected to analysis of variance found to be significant. The highest value for serum albumin was observed in $\mathrm{T}_{4}$ group. Whereas lowest value was observed in treatment group $\mathrm{T}_{0}$ fed normal diet as per BIS, 2007. The data pertaining values of serum globulin $(\mathrm{mg} / \mathrm{dl})$ subjected to analysis of variance found to be significant. The values for treatment group $\mathrm{T}_{0}$ to $\mathrm{T}_{4}$ with mean $(\mathrm{mg} / \mathrm{dl})$ were $1.59 \pm 0.21$, $1.71 \pm 0.18,1.7 \pm 0.16,1.87 \pm 0.07,2.2 \pm 0.04$ and $1.81 \pm 07$. It was observed that group $\mathrm{T}_{4}$ fed with blends of acidifier with probiotic showed numerically highest value among all the treatment group. However control group showed numerically lowest value. The values for treatment groups of serum cholesterol $(\mathrm{mg} / \mathrm{dl}) \quad$ were $\quad \mathrm{T}_{0}-229.88 \pm 7.43, \quad \mathrm{~T}_{1^{-}}$ 220.38 $\pm 13.96, \quad \mathrm{~T}_{2}-212.08 \pm 26.67, \quad \mathrm{~T}_{3^{-}}$ $201.44 \pm 12.73$ and $\mathrm{T}_{4}-192.32 \pm 15.19$ with mean 211.22 \pm 7.29 . Non-significant differences were found among the treatments. Highest numerical value of serum cholesterol was observed in control group $(229.88 \mathrm{mg} / \mathrm{dl})$ whereas lowest value of serum cholesterol was in group $\mathrm{T}_{4}(192.32 \mathrm{mg} / \mathrm{dl})$. It was observed that all treatment groups recorded lower value for serum cholesterol as compared to control. The data pertaining values of BUN (mg/dl), subjected to analysis of variance found to be significant. The values of BUN for different treatment groups were $\mathrm{T}_{0}-1.02 \pm 0.04, \mathrm{~T}_{1}-0.87 \pm 0.03, \mathrm{~T}_{2}$ $0.85 \pm 0.02 \quad \mathrm{~T}_{3}-0.77 \pm 0.02$ and $\mathrm{T}_{4}-0.7 \pm 0.02$ with mean $0.84 \pm 0.02$. Group $\mathrm{T}_{4}$ significantly lower BUN as compared to control. It was observed that all treatment groups recorded lower value for BUN as compared to control.

The results of the immune parameter corroborates with Ozek et al., (2011) who found organic acid and essential oil mixture + organic acid supplementation in diets in summer season on immune response of laying hens. 
Table.1 Composition of broiler ration

\begin{tabular}{|c|c|c|c|c|c|c|c|c|c|c|c|c|c|c|c|}
\hline \multirow[t]{2}{*}{ Ingredient } & \multicolumn{5}{|c|}{ Pre-Starter } & \multicolumn{5}{|c|}{ Starter } & \multicolumn{5}{|c|}{ Finisher } \\
\hline & $\mathbf{T}_{0}$ & $\mathbf{T}_{1}$ & $\mathbf{T}_{2}$ & $\mathbf{T}_{3}$ & $\mathbf{T}_{4}$ & $\mathbf{T}_{0}$ & $\mathbf{T}_{1}$ & $\mathbf{T}_{2}$ & $\mathbf{T}_{3}$ & $\mathbf{T}_{4}$ & $\mathbf{T}_{\mathbf{0}}$ & $\mathbf{T}_{1}$ & $\mathbf{T}_{2}$ & $\mathbf{T}_{3}$ & $\mathbf{T}_{4}$ \\
\hline Maize & 46.2 & 46.2 & 46.2 & 46.2 & 46.2 & 49 & 49 & 49 & 49 & 49 & 54 & 54 & 54 & 54 & 54 \\
\hline Soya (DOC) & 43.5 & 43.5 & 43.5 & 43.5 & 43.5 & 40.6 & 40.6 & 40.6 & 40.6 & 40.6 & 35.1 & 35.1 & 35.1 & 35.1 & 35.1 \\
\hline Soya oil & 5.57 & 5.57 & 5.57 & 5.57 & 5.57 & 6.3 & 6.3 & 6.3 & 6.3 & 6.3 & 6.92 & 6.92 & 6.92 & 6.92 & 6.92 \\
\hline L-Lysine & 0.01 & 0.01 & 0.01 & 0.01 & 0.01 & - & - & - & - & - & - & - & - & - & - \\
\hline DL-Methionine & 0.19 & 0.19 & 0.19 & 0.19 & 0.19 & 0.19 & 0.19 & 0.19 & 0.19 & 0.19 & 0.19 & 0.19 & 0.19 & 0.19 & 0.19 \\
\hline LSP & 1.13 & 1.13 & 1.13 & 1.13 & 1.13 & 1.15 & 1.15 & 1.15 & 1.15 & 1.15 & 1.1 & 1.1 & 1.1 & 1.1 & 1.1 \\
\hline DCP & 2.01 & 2.01 & 2.01 & 2.01 & 2.01 & 1.86 & 1.86 & 1.86 & 1.86 & 1.86 & 1.79 & 1.79 & 1.79 & 1.79 & 1.79 \\
\hline Trace-min mix & 0.5 & 0.5 & 0.5 & 0.5 & 0.5 & 0.3 & 0.3 & 0.3 & 0.3 & 0.3 & 0.3 & 0.3 & 0.3 & 0.3 & 0.3 \\
\hline Vit mix & 0.30 & 0.30 & 0.30 & 0.30 & 0.30 & 0.15 & 0.15 & 0.15 & 0.15 & 0.15 & 0.15 & 0.15 & 0.15 & 0.15 & 0.15 \\
\hline Salt & 0.30 & 0.30 & 0.30 & 0.30 & 0.30 & 0.3 & 0.3 & 0.3 & 0.3 & 0.3 & 0.3 & 0.3 & 0.3 & 0.3 & 0.3 \\
\hline Choline chloride & 0.1 & 0.1 & 0.1 & 0.1 & 0.1 & 0.05 & 0.05 & 0.05 & 0.05 & 0.05 & 0.05 & 0.05 & 0.05 & 0.05 & 0.05 \\
\hline Coccidiostat* & 0.10 & 0.10 & 0.10 & 0.10 & 0.10 & 0.05 & 0.05 & 0.05 & 0.05 & 0.05 & 0.05 & 0.05 & 0.05 & 0.05 & 0.05 \\
\hline Toxin binder* & 0.10 & 0.10 & 0.10 & 0.10 & 0.10 & 0.1 & 0.1 & 0.1 & 0.1 & 0.1 & 0.1 & 0.1 & 0.1 & 0.1 & 0.1 \\
\hline Sodium diformate* & - & 0.2 & 0.2 & - & - & - & 0.2 & 0.2 & - & - & - & 0.2 & 0.2 & - & - \\
\hline Probiotic* & - & - & 0.02 & - & 0.2 & - & - & 0.02 & - & 0.02 & - & - & 0.02 & - & 0.02 \\
\hline Acid Mixtures* & - & - & - & 0.2 & 0.02 & - & - & - & 0.2 & 0.2 & - & - & - & 0.2 & 0.2 \\
\hline Total & 100 & 100 & 100 & 100 & 100 & 100 & 100 & 100 & 100 & 100 & 100 & 100 & 100 & 100 & 100 \\
\hline CP $(\%)$ & 23 & 23 & 23 & 23 & 23 & 22 & 22 & 22 & 22 & 22 & 20 & 20.1 & 20.1 & 20.1 & 20.1 \\
\hline ME (Kcal/kg) & 3000 & 3000 & 3000 & 3000 & 3000 & 3100 & 3100 & 3100 & 3100 & 3100 & 3200 & 3200 & 3200 & 3200 & 3200 \\
\hline
\end{tabular}

*Over and above

Table.2 Immune and blood biochemical parameters

\begin{tabular}{|c|c|c|c|c|c|c|}
\hline Treatments & $\begin{array}{c}\text { HI Titre } \\
\left(\log _{2}\right)\end{array}$ & $\begin{array}{c}\text { Total Protein } \\
\text { (mg/dl) }\end{array}$ & Albumin (mg/dl) & $\begin{array}{c}\text { Globulin } \\
\text { (mg/dl) }\end{array}$ & Cholesterol (mg/dl) & BUN (mg/dl) \\
\hline T0 & $4^{\mathrm{a}} \pm 0.42$ & $2.95^{\mathrm{a}} \pm 0.25$ & $1.36^{\mathrm{a}} \pm 0.1$ & $1.59^{a} \pm 0.21$ & $229.88^{a} \pm 7.43$ & $1.02^{\mathrm{d}} \pm 0.04$ \\
\hline T1 & $4.13^{\mathrm{a}} \pm 0.52$ & $3.14^{\mathrm{ab}} \pm 0.16$ & $1.43^{\mathrm{a}} \pm 0.1$ & $1.71^{\mathrm{a}} \pm 0.18$ & $220.38^{\mathrm{a}} \pm 13.96$ & $0.87^{\mathrm{c}} \pm 0.03$ \\
\hline $\mathbf{T 2}$ & $4.25^{\mathrm{a}} \pm 0.49$ & $3.24^{\mathrm{ab}} \pm 0.26$ & $1.54^{\mathrm{ab}} \pm 0.12$ & $1.7^{\mathrm{a}} \pm 0.16$ & $212.08^{a} \pm 26.67$ & $0.85^{b c} \pm 0.02$ \\
\hline T3 & $4.38^{\mathrm{a}} \pm 0.6$ & $3.69^{b c} \pm 0.14$ & $1.82^{b} \pm 0.12$ & $1.87^{\mathrm{ab}} \pm 0.07$ & $201.44^{\mathrm{a}} \pm 12.73$ & $0.77^{\mathrm{ab}} \pm 0.02$ \\
\hline T4 & $5^{\mathrm{a}} \pm 0.68$ & $4.06^{\mathrm{c}} \pm 0.1$ & $1.86^{\mathrm{b}} \pm 0.1$ & $2.2^{\mathrm{b}} \pm 0.04$ & $192.32^{a} \pm 15.19$ & $0.7^{\mathrm{a}} \pm 0.02$ \\
\hline Pooled Mean & $4.35 \pm 0.24$ & $3.41 \pm 0.1$ & $1.6 \pm 0.06$ & $1.81 \pm 0.07$ & $211.22 \pm 7.29$ & $0.84 \pm 0.02$ \\
\hline
\end{tabular}


No significant differences were observed in antibody titer level of Newcastle disease virus (NDV), however, supplementing essential oil mixture and organic acid in layer diet tend to improve antibody responses against NDV.

Similar results were found to Manafi et al., (2015, 2018), Yakhkeshi et al., (2011), Hassanein and Soliman (2010) .In contrast to above results Flamand et al., (2014) found no effect on immune response by administering the organic acid blends. The results obtained in present study for serum total protein are in accordance with Yesilbag and Colpan (2006) who studied the effects of organic acid supplemented diets $(0.5,1.0$, and $1.5 \%)$ on serum parameters in 20 week old 180 Lohmann LSL white layer hens showing significant increase in total protein. Linear increase in serum total protein was observed by Soltan (2008). This effect of organic acid supplementation on protein metabolism may be related to improvement of intestinal amino-acids absorption in acidic conditions that consequently enhances protein synthesis. Whereas Hassanein and Soliman (2010) reported that total protein levels of birds fed $0.4 \%$ (3.82), $0.8 \%$ (3.65) and $1.2 \%$ (3.97) yeast was lower than the control (4.16). Similarly Brzoska et al., (2013) reported no significant differences between the control and experimental chickens for serum total protein. Naveenkumar et al., (2018) also reported non-significant differences for serum total protein. The results of serum albumin were found to be similar with Yesilbag and Colpan (2006) who found significant increase in serum albumin. Soltan (2008) also reported linear increase of serum concentration of albumin. However Hassanein and Soliman (2010) reported decreased value of serum albumin of treatment group than control. Results of the present study for serum globulin are in agreement with Abdel-Fttah et al., (2008) who supported that dietary organic acid supplementation increases serum globulin level significantly compared to control diet which improve the immune response. Globulin level has been used as indicator of immune responses and source of antibody production. Griminger (1986) stated that high globulin level signify better disease resistance and immune response. The outcome of present study for serum cholesterol level found to be similar with Abdel-Fttah et al., (2008) where serum cholesterol level decreases significantly in treatment diets supplemented with organic acid. Hassanein and Soliman (2010) observed cholesterol levels of layers fed yeastsupplemented diets were lower than the control. Kazempour and Jahanian (2017), Ramigani et al., (2015) also reported decrease in serum cholesterol levels in organic acid supplemented groups. However Yesilbag and Colpan (2006), Adil et al., (2010) and Brzoska et al., (2013) reported no difference in value of total cholesterol on different dietary treatment supplemented with organic acids. The values of results for BUN were found to be similar with biochemical profile of chicken given by Abdi-Hachesoo (2011).

\section{Acknowledgments}

Special thanks to Dr. D.H Rekhate (ExProfessor \& Head, Dept. of ANN, PGIVAS, Akola), Dr. R.N. Dhore (Ex-Professor\& Head, Dept. of ANN, PGIVAS, Akola) for their valuable guidance and suggestions and Dr. Vijay Tijare (GM-Venkys Ind. Pvt. Ltd, Pune.) for valuable guidance and sponsoring feed additives required.

\section{References}

Abbas G., H.K. Sohail and Habib-Ur R. 2013. Effects of formic acid administration in the drinking water on production performance, egg quality and immune system in layers during hot season. Avian Biol. Res. 6(3):227-232. 
Abdel-Fttah S.A., M.H. EI-Mednay and Abdel-Azeem F. 2008. Thyroid activity some blood constituents, organs morphology and performance of broiler chicks fed supplemental organic acids. Int. J. Poult. Sci. 7(3): 215-222.

Abdi-Hachesoo Bahman 2011. Biochemical profile of chicken. Global Veterinaria. 7(3): 238-241.

Adil S., B. Tufail, A.B. Gulam, S. Masood and Manzoor R. 2010. Effect of dietary supplementation of organic acids on performance, intestinal histomorphology, and serum biochemistry of broiler chicken. Vet. Med. Int. 1-7. doi.org/10.4061/2010/479485.

Attia, Y.A., B.M. Böhmer and Roth-Maier D.A. 2006. Responses of broiler chicks raised under constant relatively high ambient temperature to enzymes, amino acid supplementations, or diet density. Arch. Geflugelkd. 70:80-91.

Attia, Y.A., H.F. Ellakany, A.E. Abd ElHamid, F. Bovera and Ghazaly S.A. 2012. Control of Salmonella enteritidis infection in male layer chickens by acetic acid and/or prebiotics, probiotics and antibiotics. Arch. Geflugelkd. 76:239-245.

Benţea, M., A. Şara, L. Pantă andClapa L.2010. The effects of enzymatic complex allzyme SSF and organic selenium on some growth and consumption indices of broiler turkey. Scientific Papers Animal Science and Biotechnologies. 43:9-14.

Brzoska Franciszek, BogdanŚliwiński and Olga Michalik-Rutkowska 2013. Effect of dietary acidifier on growth, mortality, post-slaughter parameters and meat composition of broiler chickens. Ann. Anim. Sci. 13(1):8596.

Capcarova, M., A. Kolesárová, P. Massanyi and Kováčik J. 2008. Selected blood biochemical and haematological parameters in turkeys after experimental probiotic Enterococcus faecium M-74 strain administration. Int. J. Poult. Sci. 7:1194-1199.

El-Deek, A.A., M.A. Al-Harthi and Attia Y.A. 2011. Effect of different dietary levels of dried eggs by-product without or with shell and/or premix on the performance of laying strain chicks from 2 to 8 wk of age. Arch. Geflugelkd. 75:169-178.

Fascina V.B., J.R. Sartori, E. Gonzales, F. Barros De Carvalho, M.G. Pereira De SouzaI, G.V. Polycarpo, A.C. Stradiotti and Pelícia V.C. 2012. Phytogenic additives and organic acids in broiler chicken diets. Braz. J. Ani. Sci. 41(10):2189-2197.

Flam and Ernesto Marin, Alma VazquezDuran and Abraham Mendez-Albores 2014. Effect of organic acid blends in drinking water on growth performance, blood constituents and immune response of broiler chickens. J. Poult. Sci., 51: 144-150.

Fuller R. 1992. History and development of probiotics. In: Fuller R (Ed.), Probiotics-The Scientific Basis. Chapman and Hall, London.

Gálik, B. and RolinecM.2011. The effect of phytogenic feed additives on the performance of non-ruminants, Proc. International Ph.D. workshop on welfare, biotechnology and quality of animal production, Nitra, Slovak University of Agriculture, 19.

Griminger, P. 1986. Lipid Metabolism in "Avian Physiology" Edited by P.D. Sturkie. 4th Edn.

Hassan H.M.A., M.A. Mohamed, Amani W. Youssef and Eman Hassan R. 2010. Effect of using organic acids to substitute antibiotic growth promoters on performance and intestinal 
microflora of broilers. Asian-Aust. J. Anim. Sci. 23(10):1348-1353.

HassaneinSaadia M. and Nagla Soliman K.2010.Effect of probiotic (Saccharomyces cerevisiae) adding to diets on intestinal microflora and performance of Hy-Line layers hens. J. Am. Sci. 6(11):159-169.

Huff G.R., W.E. Huff, M.B. Farnell, N.C. Rath, D.LS.F. Solis and Donoghu A.M.2010. Bacterial clearance, heterophil function, and hematological parameters of transport-stressed turkey poults supplemented with dietary yeast extract. Poult. Sci. 89: 447-456.

KazempourF. and Jahanian R.2017.Effects of different organic acids on performance, ileal microflora, and phosphorus utilization in laying hens fed diet deficient in non-phytate phosphorus. Ani. Feed Sci. Tech. 223:110-118.

Král, M., M. Angelovičová, L. Mrázová, J. Tkáčová and Kliment M.2011. Probiotic and acetic acid of broiler chickens performance. Scientific Papers Animal Science and Biotechnologies. 44: 149-152.

Lohakare J.D., M.H. Ryu, T.W. Hahn, J.K. Lee and Chae B.J.2005.Effects of supplemental ascorbic acid on the performance and immunity of commercial broilers. J. Appl. Poultry Res. 14:10-19.

Madsen K.L., A. Cornish, P. Soper, C. McKaigney, H. Jijon, C. Yachimec, J. Doyle, L. Jewell and DeSimone C. 2001.Probiotic bacteria enhance murine and human intestinal epithelial barrier function. Gastroenterology. 121: 580-591.

ManafiM., M. Hedayati and Mirzaie S.2018.Probiotic Bacillus species and Saccharomyces boulardii improve performance, gut histology and immunity in broiler chickens. South
African Journal of Animal Science, 48(No. 2).

ManafiMilad 2015. Comparison study of a natural non-antibiotic growth promoter and a commercial probiotic on growth performance, immune response and biochemical parameters of broiler chicks. J. Poult. Sci., 52: 274-281.

NaveenkumarS., N. Karthikeyan, R. Narendra Babu, P. Veeramani, S. Sivarama Krishnani and Srinivasan G.2018.Effect of calcium propionate and coated sodium butyrate as an alternative to antibiotic growth promoters on the serum profile of commercial broiler chicken. Int. J. Cem. Sci. 6(1): 36-39.

OIE (1992) Manual of standards for diagnostic test and vaccines off Int.Epizootics, Paris

OzekK., K.T. Wellmann, B. Ertekin andTarım B.2011.Effects of dietary herbal essential oil mixture and organic acid preparation on laying traits, gastrointestinal tract characteristics, blood parameters and immune response of laying hens in a hot summer season. J. Anim. Feed Sci. 20:575-586.

Petruška, P., E. Tusimova, A. Kalafova, P. Hascik, M. Kacaniova, A. Kolesarova and Capcarova M. 2012. Effect of propolis in chicken diet on selected parameters of mineral profile. JMBFS. 1:1090-1097.

Ramigani V.R., J.V. Ramana, D. Rao Srinivasa, S. Shakila and Suresh J. 2015. Effect of dietary supplementation of organic acids on digestibility of nutrients and serum biochemical profile of broiler chicken. Ind. J. Ani. Nutri. 32(3): 300 -304.

S.P.S.S.2009. Statistical Package for the Social Sciences Version.

Sherman P.M., J.C. Ossa and Johnson-Henry 
K.2009.Unravelling mechanisms of action of probiotics. Nutrition Clinical Practice 21:10-14.

Snedecor G.W. and Corchan W.G. 1994. Statistical Method, $9^{\text {th }}$ Edition, Oxford and IBH publishing Co. Pvt. Ltd, New Delhi.

Soltan M.A. 2008.Effect of dietary organic acid supplementation on egg production, egg quality and some blood serum parameters in laying hens. Int. J. Poult. Sci. 7(6): 613-621.

Yakhkeshi S., S. Rahimi and Gharib Naseri K. 2011.The effects of comparison of herbal extracts, antibiotic, probiotic and organic acid on serum lipids, immune response, GIT microbial population, intestinal morphology and performance of broilers. J. Med. Plants. 1(37): 80-95.

Yesilbag D. and Colpan I. 2006. Effects of Organic acid supplemented diets on growth performance, egg production and quality and on serum parameters in laying hens. Redee. Med. Vest. 157(5): 280-284.

\section{How to cite this article:}

Jadhao, G.M., D.H. Sawai, H.N. Rewatkar, R.P. Kolhe, A.P. Bansod and Nandeshwar, J.D. 2019. Effect of Organic Acids with Probiotic Supplementation on Immunity and Blood Biochemical Status of Broiler Chicken. Int.J.Curr.Microbiol.App.Sci. 8(02): 1952-1959. doi: https://doi.org/10.20546/ijcmas.2019.802.227 